\title{
PENDEKATAN DESAIN KESEHARIAN PADA EKOWISATA MANGROVE DI DESA PANTAI MEKAR, MUARA GEMBONG, BEKASI
}

\author{
Gracia Kristina ${ }^{1)}$, Timmy Setiawan ${ }^{21}$ \\ 1)Program Studi S1 Arsitektur, Fakultas Teknik, Universitas Tarumanagara, graciagabriela15@yahoo.com \\ 2)Program Studi S1 Arsitektur, Fakultas Teknik, Universitas Tarumanagara, timmys@ft.untar.ac.id
}

\begin{abstract}
Abstrak
Mangrove merupakan salah satu tanaman yang tumbuh subur di sepanjang pantai yang ada di Indonesia. Keberadaan ekosistem mangrove membawa berbagai dampak dan manfaat, baik bagi makluk hidup, lingkungan maupun masyarakat disekitar pesisir pantai. Masyarakat memanfaatkan mangrove yang melimpah dan kaya manfaat ini untuk memenuhi kebutuhan sehari-hari, mulai dari akar, batang daun hingga buahnya. Pemanfaatan Mangrove secara besar-besaran mengakibatkan rusaknya ekosistem Mangrove. Proyek Ekowisata Mangrove bertujuan untuk memperbaiki ekosistem mangrove yang ada akibat degradasi serta memperkenalkan pemanfaatan buah mangrove yang lebih ramah lingkungan, tidak merusak ekosistem mangrove dengan tidak menebang akar - batang dan menghasilkan nilai ekonomi. Dalam Kamus Besar Bahasa Indonesia (KBBI), degradasi diartikan sebagai kemunduran, kemerosotan dan penurunan. Proyek Ekowisata Mangrove ini menggunakan metode keseharian. Ekowisata mangrove berusaha untuk memberikan gambaran keseharian sebagai pengantar awal dari mulai pembenihan hingga pohon mangrove dapat tumbuh. Partisipatif dengan mengajak dan memperlihatkan kepada pengunjung pemanfaatan mangrove yang tidak menebang pohon mangrove semata serta pengungkapan realitas ekosistem mangrove dengan adanya rekreasi, observation deck dan taman mangrove. Ekowisata Mangrove terletak di Desa Pantai Mekar, Muara Gembong, Bekasi, tapak perancangan berada di lahan yang dikelilingi oleh tumbuhan mangrove. Pada program Ekowisata Mangrove terdapat beberapa program yaitu pembenihan dan penanaman mangrove, spa, Pengolahan buah mangrove untuk produk kecantikan dan workshop jajanan yang berbahan dasar mangrove serta berbagai program penunjang lainnya seperti restoran, area rekreasi, dsb.
\end{abstract}

\section{Kata kunci: Degradasi; Ekowisata; Ekosistem Mangrove}

\begin{abstract}
Mangrove is one of the plants that thrives along the coast in Indonesia. The existence of the mangrove ecosystem brings impacts and benefits, both for living things, the environment and the community around the coast. People use mangroves to meet their daily needs, from roots, leaf stems to fruit. Massive use of mangroves has resulted in damage to the mangrove ecosystem. The Mangrove Ecotourism Project aims to improve the existing mangrove ecosystem due to degradation and introduce the use of mangrove fruit that is more environmentally friendly, does not damage the mangrove ecosystem by not cutting down the roots and generating economic value. In Kamus Besar Bahasa Indonesia (KBBI), Degradation is defined as a setback and decline. The Mangrove Ecotourism project uses the Everydayness method. By using the Everydayness method, Mangrove Ecotourism seeks to provide a daily picture as an initial introduction from seeding until mangrove trees can grow. mangrove park. Mangrove Ecotourism is located in Pantai Mekar Village, Muara Gembong, Bekasi, the design site is on land equipped with mangroves. In the Mangrove Ecotourism program, there are several programs, namely mangrove seeding and planting, spa, mangrove fruit processing for beauty products and snack workshops made from mangroves as well as various other supporting programs such as restaurants, recreation areas, etc.
\end{abstract}

\section{Keywords: Degradation; Ecotourism; Mangrove Ecotourism}




\section{PENDAHULUAN}

\section{Latar Belakang}

Kawasan pesisir erat kaitannya dengan ekosistem Mangrove. Mangrove sebagai penghubung antara ekosistem daratan dan lautan serta garda terdepan dalam melindungi kawasan pesisir. Hidup di ekosistem pesisir, mangrove dipengaruhi oleh aktivitas pasang surut air laut dan substrat yang berlumpur. Mangrove tumbuh dengan baik dikawasan dan mampu bertahan di kondisi yang ekstrim serta membentuk suatu ekosistem yang dikenal dengan ekosistem mangrove. Ekosistem mangrove memiliki banyak manfaat dan peran penting didalam kehidupan, mulai dari aspek lingkungan, ekonomi, kesehatan, dsb. Indonesia memiliki $22.6 \%$ luas kawasan mangrove dari total luasan mangrove yang ada di dunia berdasarkan data dari Food and Agriculture Organization of United Nations pada tahun 2007 atau setara dengan 3.112.989 ha. Memiliki sumber daya dan manfaat mangrove yang melimpah mendorong masyarakat untuk memanfaatkan mangrove dalam memenuhi kebutuhan sehari-hari. Lambat laun pemanfaatan mangrove untuk memenuhi kebutuhan yang terus meningkat membawa dampak dan permasalahan yang besar. Tingginya degredasi kawasan mangrove di Indonesia salah satunya diakibatkan oleh pemanfaatan manusia. Kerusakan ekosistem mangrove yang disebabkan oleh manusia umumnya dilatarbelakangi oleh kurangnya kepedulian akan kelestarian mangrove, diantaranya penebangan kayu secara berlebihan, pembukaan lahan menjadi tambak, perkebunan kelapa sawit, penebangan ilegal,dsb.

Pemanfaatan mangrove secara eksplosif selama dekade terakhir membawa dampak yang beragam, banjirnya kawasan pesisir, abrasi yang semakin meningkat, hingga penyerapan gas karbon yang semakin menurun akibat ekosistem mangrove yang rusak. Ketidakseimbangan akibat kerusakan mangrove tidak hanya berdampak pada ekosistem mangrove semata, mengingat mangrove juga merupakan habitat bagi biota laut dan makhluk hidup di hutan mangrove tersebut. Kerugian dari aspek ekonomi dan ekologi akan terus terjadi dan terus bertambah bila eksploitasi mangrove terus berlangsung. Berdasarkan data Kementrian Lingkungan Hidup dan Kehutanan (KLHK, 2018), laju kerusakan hutan mangrove seluas 58.000 ha per tahun. Angka ini merupakan laju kerusakan tercepat di dunia. Data tersebut menyebutkan bahwa faktor utama kerusakan mangrove adalah adanya alih fungsi menjadi lahan pertanian, tambak udang, pembangunan infrastruktur dan pemanfaatan yang mengeksploitasi. Berdasarkan peraturan Menteri Kelautan dan Perikanan nomor 75 tahun 2016, Pemerintah telah melarang pembuatan tambak baru di kawasan hutan mangrove dan di zona inti kawasan konservasi. Terjadinya pembukaan kawasan hutan mangrove untuk dimanfaatkan dengan menjadikannya perkebunan sawit turut menyumbangkan kerusakan terhadap ekosistem mangrove. Berdasarkan data Kementrian Lingkungan Hidup dan Kehutanan (KLHK, 2017) memperlihatkan 1.82 juta ha mangrove dari total keseluruhan 3.49 ha berada dalam kondisi rusak. Penyebab lainnya yang menyumbangkan kerusakan mangrove dengan jumlah yang besar berupa adanya pembalakan liar kawasan mangrove yang dilatarbelakangi oleh berbagai sebab, mulai dari pemanfaatan kayu mangrove hingga pembukaan lahan kawasan mangrove untuk kepentingan lainnya.

\section{Rumusan Permasalahan}

Upaya dalam bidang arsitektur dalam mengkonservasi dan mengurangi eksploitasi mangrove sebagai bentuk melampaui ekologi menuju arsitektur untuk kebaikan dan kehidupan, serta peran arsitektur dalam tantangan ekonomi pesisir yang berkaitan dengan eksploitasi mangrove.

\section{Tujuan}

Program Ekowisata Mangrove menjadi wadah untuk memfasilitasi dalam upaya menanggulangi ketidakseimbangan akibat dampak eksploitasi mangrove terhadap kerusakan ekosistem 
mangrove dan degradasi mangrove, serta menjadi wadah untuk meningkatkan kesadaran dan kepedulian masyarakat akan pentingnya keberadaan mangrove.

\section{KAJIAN LITERATUR \\ Mangrove}

Berdasarkan Food and Agriculture Organization of United Nations, Hutan Mangrove merupakan suatu komunitas tumbuhan yang tumbuh pada area pasang surut dengan kondisi tanah berlumpur, berpasit atau lumpur berpasir. Menurut Ana (2015) berdasarkan Balai riset dan SDM Kelautan dan Perikanan (Kementrian Kelautan dan Perikanan) menyatakan beberapa manfaat dari mangrove yaitu sebagai habitat bagi perikanan, mencegah terjadinya erosi pantai, sebagai katalis tanah dari air laut, memberikan dampak dari segi ekonomi, sumber pakan bagi ternak, menjaga keseimbangan kualitas air dan udara, mencegah terjadinya pemanasan global, menyediakan kayu bakar, sebagai sumber pendapatan bagi nelayan pantai, objek untuk kawasan pariwisata, penelitian untuk pengembangan ilmu pengetahuan serta menjaga iklim dan cuaca. Dalam Kamus Besar Bahasa Indonesia (KBBI) degradasi diartikan sebagai kemunduran, kemerosotan dan penurunan.

Buku The Distribution of Degraded Mangrove Ecosystem in Indonesia pada tahun 2018 yang merupakan hasil kolaborasi Kementrian Koordinator Bidang Kemaritiman dan Kementrian Lingkungan Hidup dan Kehutanan membahas dan memperlihatkan bahwa degradasi mangrove terjadi hampir di setiap provinsi di Indonesia. Penurunan luas mangrove terbesar yang terjadi di Indonesia disebabkan oleh perubahan fungsi menjadi tambak dan perkebunan kelapa sawit. Center for International Foresty Research (CIFOR,2015:7) menyatakan bahwa tumbuhan mangrove melindungi sepanjang garis pantai yang ada di Indonesia dari gelombang badai, kenaikan air permukaan laut dan tsunami. Mangrove turut berperan dalam mendukung perikanan di sekitar pantai dan meningkatkan potensi pariwisata. Indonesia memiliki seperempat dari keseluruhan mangrove yang ada di Dunia, hal ini menjadi tantangan dengan ancaman laju degradasi mangrove yang tinggi bagi Indonesia dengan kehilangan 52.000 ha mangrove setiap tahunnya.

Luas hutan mangrove yang terus mengalami penurunan hingga $30-50 \%$ diakibatkan oleh pembangunan daerah pesisir, perluasan pembangunan area tambak dan penebangan yang berlebihan terhadap mangrove. Deforestasi dan terjadinya perubahan tata guna lahan menyebabkan emisi karbon dioksida yang bersumber dari aktivitas manusia (CIFOR, 2012:12(1)). Hutan mangrove dikenal sebagai salah satu hutan dengan simpanan karbon tertinggi dibandingkan rerata simpanan karbon diberbagai tipe hutan lainnya di dunia. Data dalam buku The Distribution of Degraded Mangrove Ecosystem in Indonesia menunjukan bahwa degradasi mangrove yang terjadi di Provinsi Jawa Barat memiliki angka degradasi mangrove melebihi 16.000 ha dengan perbandingan mangrove dengan kondisi baik kurang dari 2.000 ha. Jurnal Perubahan Lahan Mangrove di Pesisir Muara Gembong, Bekasi, Jawa Barat menjabarkan kawasan lahan mangrove yang terdapat di Kecamatan Muara Gembong pada setiap desanya mengalami perubahan selama waktu 2009 hingga 2019. Perubahan yang terjadi berupa adanya penambahan luasan, pengurangan luasan dan lahan mangrove yang tetap bertahan. Penambahan luasan ditumbuhi mangrove terjadi pada daerah yang terletak dekat dengan muara sungai dan memiliki batasan langsung dengan perairan. Kecamatan Muara Gembong ditetapkan sebagai kawasan konservasi Mangrove dengan adanya usaha penanaman mangrove di berbagai lokasi desa di Muara Gembong Bekasi.

\section{Beyond Ecology}

Pada paparan yang disampaikan dalam kuliah tamu oleh Agustinus Sutanto (2021), terdapat beberapa acuan kerja dalam berarsitektur menuju tercapainya "Beyond Ecology" diantaranya 
adalah Energy and Emission (Kemampuan dalam mendesain untuk menerapkan nol emisi CO2 pada pengoprasian bangunan dan meminimalisir efek karbon yang terjadi baik dari material maupun konstruksi); Adaptation (kemampuan dalam mempelajari dan merancang yang berkaitan dengan berbagai kemungkinan dampak yang terjadi seperti naiknya suhu di bumi, naiknya permukaan air laut, terjadinya kekeringan, terjadinya banjir, kelangkaan akan pangan dan perubahan populasi); Resilience (kemampuan untuk merancang kelanjutan "hunian" dan penanggulangan untuk memulihkan cepat setelah terjadinya bencana seperti bencana alam dan perubahan iklim); Sustainable Digital (kemampuan untuk membaca data lingkungan sebagai suatu kesatuan besar dalam menentukan strategi dalam merancang kualitas spasial); New Technology (kemampuan dalam memanfaatkan teknologi yang terbarukan dalam meningkatkan kualitas dan merapkannya pada ruang maupun konstruksi dan program bangunan yang diusulkan); Context (kemampuan dalam melihat kesetempatan kaitannya dengan hubungan terhadap lingkungan sekitar sebagai sebuah konfigurasi keruangan).

\section{METODE}

\section{Metode Pengumpulan Data}

Pengumpulan data dilakukan secara kualitatif dengan mengumpulkan dan mempelajari studi sebelumnya yang bersumber dari studi literatur, buku, jurnal, makalah dan website terkait pembahasan.

\section{Metode Desain}

Penggunaan metode keseharian dalam mendesain. Dalam buku metode Desain (Agustinus, 2020:152-154) menggambarkan arsitektur keseharian sebagai suatu bentuk respon sederhana yang memiliki kaitan langsung dengan kenyataan, tidak mengacu melalui ide-ide abstrak melainkan melihat kenyataan sebagai suatu referensi dalam melakukan tindakan. Terdapat 3 strategi yang diulas untuk menggunakan metode keseharian dalam berarsitektur. Ketiga strategi tersebut yaitu drawing the everyday, story telling, dan dialogue, dengan penjabaran seperti Drawing the Everyday (berusaha untuk menggambarkan keseharian, membaca dan mengolah cara masyarakat dalam menghasilkan ruang sosial melalui aktivitas kesehariannya); Story Telling (melalui pendekatan dialogis atau pendekatan partisipatif, membuat atau menjadikan adanya ruang sebagai interaksi untuk menarik masyarakat turut berkontribusi); Dialogue (Adanya pengungkapan realitas yang terjadi baik melalui cerita, melihat, mendengar serta merasakan melalui keseharian yang ada).

\section{DISKUSI DAN HASIL}

\section{Program Rancangan}

Mangrove memiliki berbagai manfaat yang kemudian dapat dimanfaatkan untuk memenuhi kebutuhan sehari-hari manusia, mulai dari pemanfaatan akar untuk aneka obat-obatan, kayu sebagai kayu bakar, bahan pakan ternak, dan berbagai manfaat bagi lingkungan. Pemanfaatan mangrove yang besar sering kali tidak diimbangi dengan penanaman kembali yang menyebabkan rusaknya ekosistem mangrove. Pemanfaatan mangrove tidak seimbang dengan upaya menjaga ekosistem mangrove membuat kawasan mangrove dengan kondisi yang baik terus mengalami penurunan. 


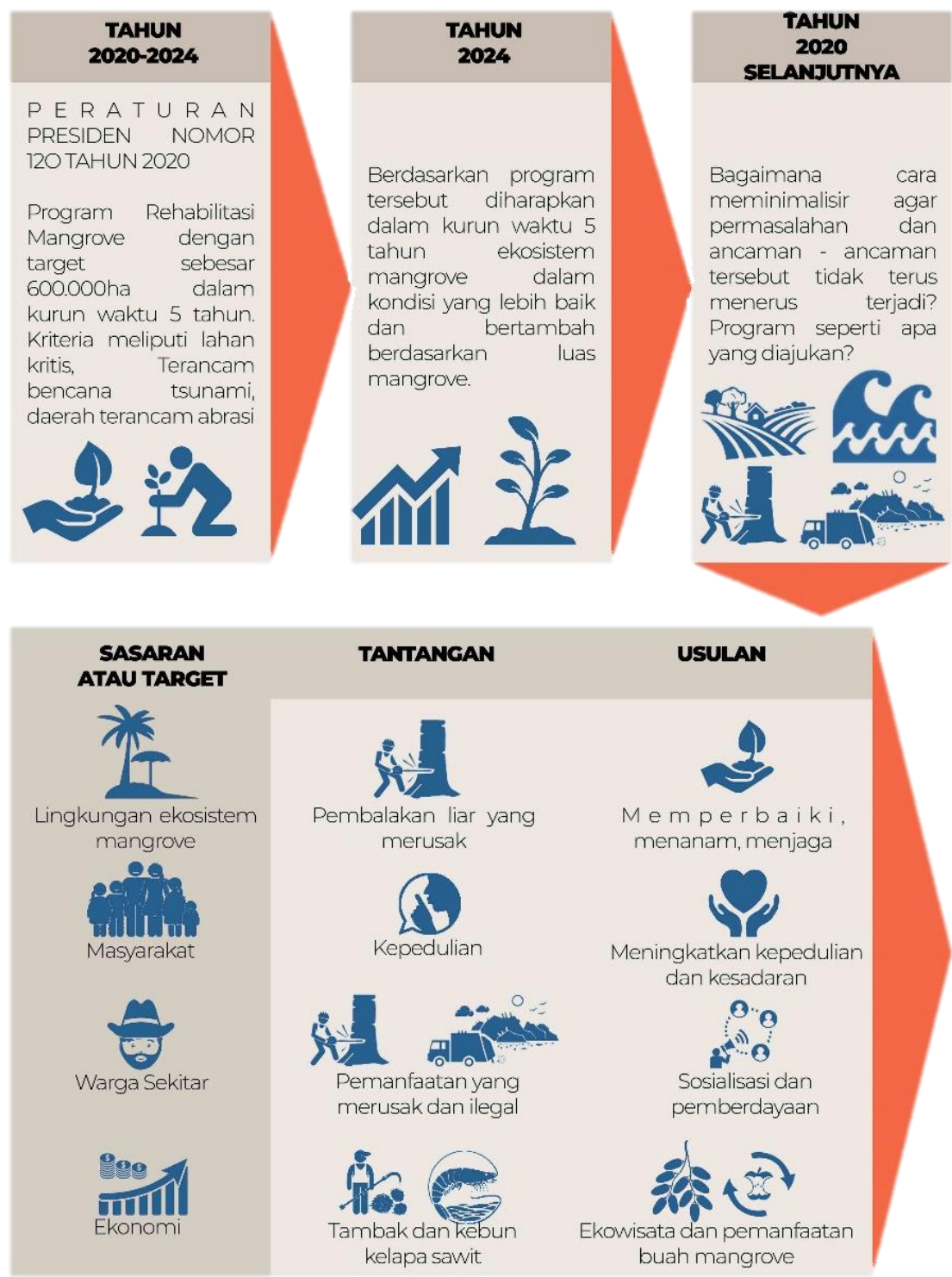

Gambar 1. Sasaran dan Usulan yang Terkait Mengenai Program

Sumber: Penulis, 2021

Program rancangan menjadi salah satu upaya kecil dalam usaha menjaga dan mengembalikan ekosistem mangrove serta mengedukasi dan mengkomunikasikan kepada masyarakat akan pentingnya menjaga mangrove dan aksi nyata dalam menjaga mangrove dengan melakukan pembenihan dan penanaman mangrove. Program Ekowisata Mangrove merupakan program rancangan arsitektur yang didalamnya terdapat beberapa kegiatan inti berupa pembenihan mangrove, pemanfaatan buah mangrove sebagai bentuk pemanfaatan mangrove yang tidak merusak lingkungan sebagai produk perawatan kecantikan dan bahan makanan, spa serta berbagai kegiatan penunjang lainnya. Berusaha untuk menguraikan program rancangan yang beriringan dengan usaha pemerintah dalam upaya menganggulangi rehabilitasi ekosistem mangrove dengan harapan ketika kondisi mangrove sudah menjadi lebih baik pemahaman, kepedulian dan dan kesadaran masyarakat untuk menjaga ekosistem mangrove menjadi lebih meningkat. 


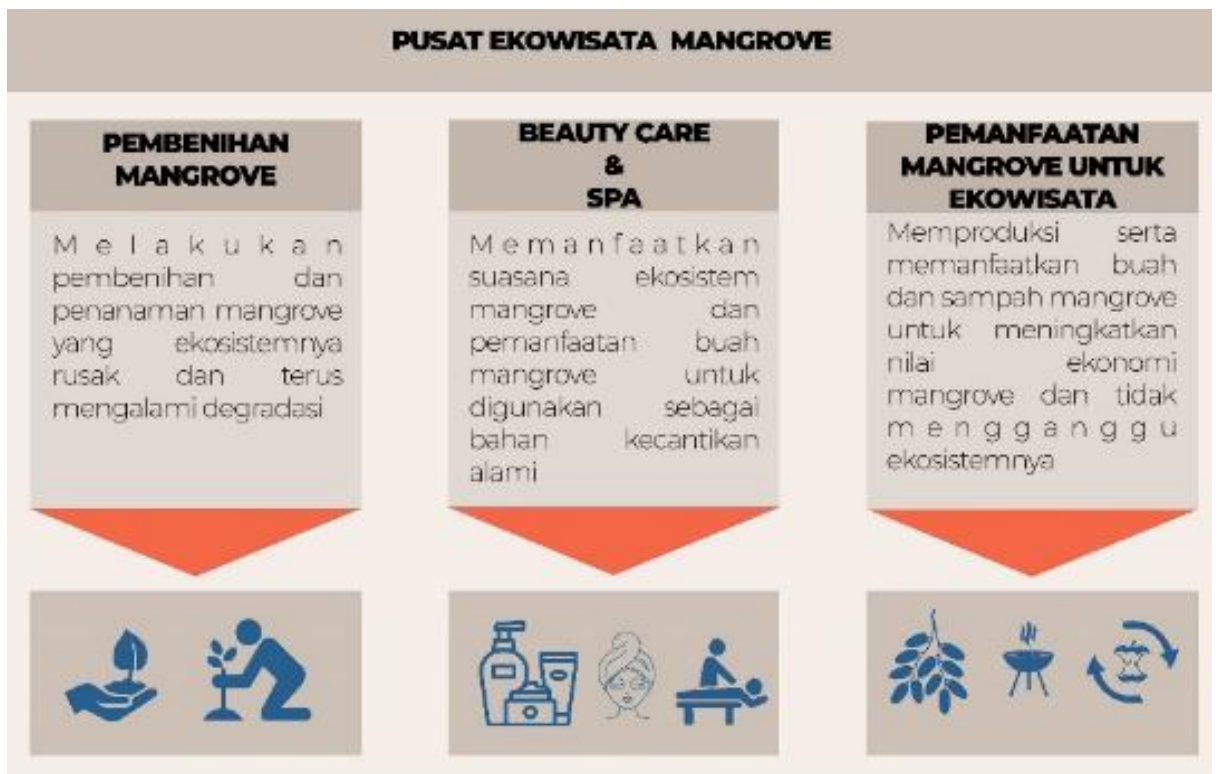

Gambar 2. Program Ekowisata

Sumber: Penulis, 2021

\section{Tapak Rancangan}

Tapak Rancangan berada di Jl. Muara Gembong Bekasi, Desa Pantai Mekar. Tapak berhadapan dengan Baramundi Mania Basecamp. Pemilihan tapak pada lokasi ini berdasarkan beberapa pertimbangan yaitu tapak berada di lokasi yang ditumbuhi dan dikelilingi oleh mangrove; memiliki tanah kosong yang dikelilingi mangrove, sehingga untuk program perancangan tidak perlu menebang dan membuka ekosistem mangrove; program perancangan sejalan dengan upaya pemerintah dalam mengembangkan pembangunan wisata di Desa Pantai Mekar, Muara Gembong, Bekasi.

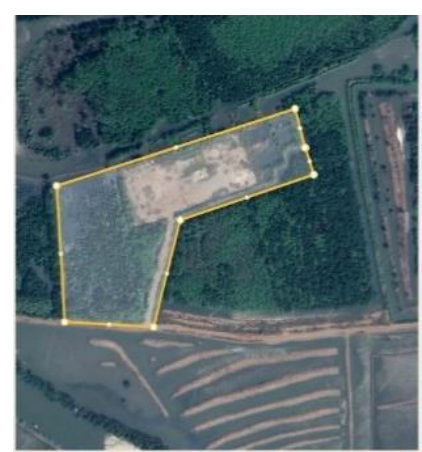

Gambar 3. Tapak Rancangan

Sumber: Google Maps, 2021

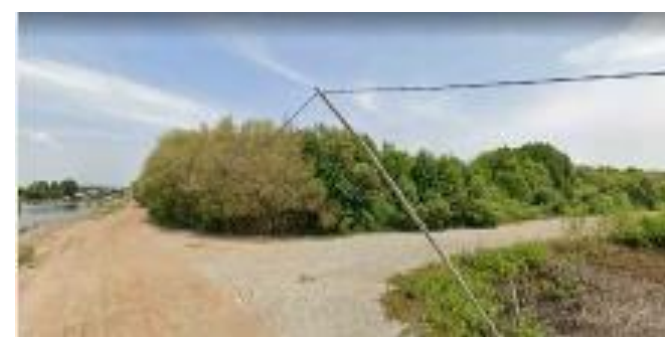

Gambar 4. Jalan utama Tapak

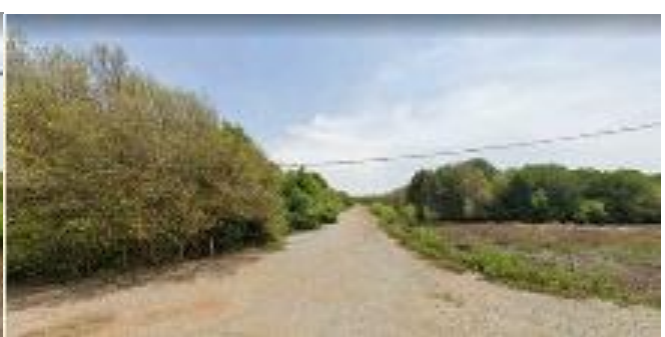

Gambar 5. Akses masuk Tapak

Sumber: Google Maps,2021 
Dalam memilih tapak rancangan mengambil referensi dari Taman Wisata Alam Mangrove Kapuk. Tapak Rancangan seluas $43.000 \mathrm{~m}^{2}, \mathrm{KDB}=5 \%, \mathrm{~KB}=2, \mathrm{KLB}=0.15, \mathrm{KTB}=0$ dan $\mathrm{KDH}=0$. Tapak Rancangan memiliki sebuah platform tanah besar pada tapak yang tidak ditumbuhi tanaman mangrove. Kondisi Tapak telah ditumbuhi mangrove dengan dialiri sungai dan beberapa area yang berlumpur.

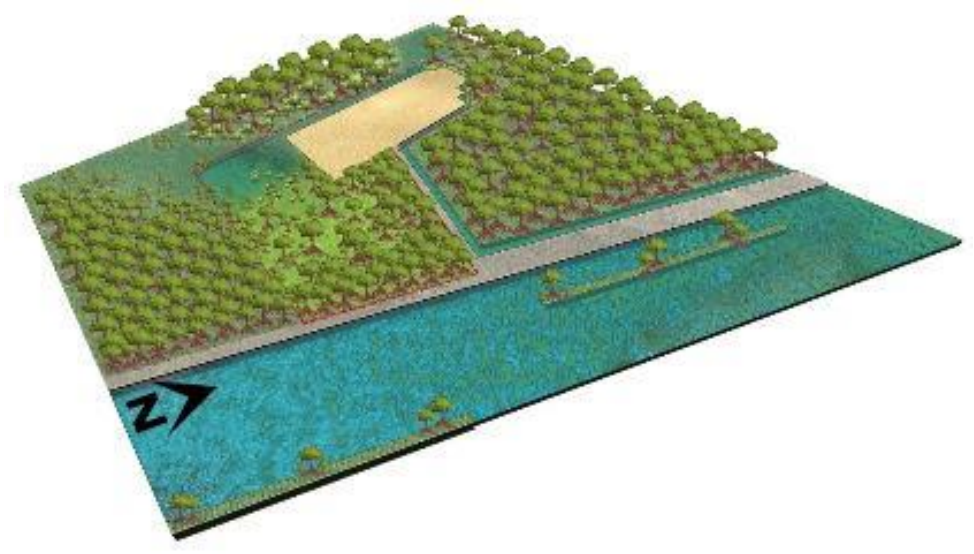

Gambar 6. Gambar Ilustrasi Tapak Rancangan Sumber: Ilustrasi Pribadi,2021

\section{Implementasi Metode Desain \\ Menggambarkan Keseharian}

Dalam kaitannya dengan Ekowisata Mangrove, Program taman mangrove sebagai gambaran keseharian, Arsitektur dalam ruang berusaha untuk memberikan gambaran awal kondisi dan permasalahan degradasi mangrove.

\section{Pendekatan Dialogis atau Partisipatif}

Sub program workshop aneka jajanan, pengolahan skincare buah mangrove serta balai pilah bilah benih mangrove sebagai wadah atau sarana agar adanya dialog atau partisipasi masyarakat setelah mengetahui fenomena degradasi mangrove yang terjadi.

\section{Pengungkapan Realitas}

Pengungkapan realitas keadaan dan habitat mangrove dengan sub program tur mangrove yang berusaha untuk mendekatkan persepsi masyarakat dengan kehidupan mangrove yang sebenarnya dan manfaat mangrove yang tidak hanya seputar untuk menjaga lingkungan. Adanya Observation Deck sehingga pengunjung dapat melihat realitas ekosistem mangrove dengan sudut pandang yang berbeda.

Membagi dan menempatkan zoning vertikal maupun horizontal. Level paling dasar sebagai level menggambarkan keseharian, memaksimalkan suasana dan kesan beradad di ekosistem mangrove. Level tengah sebagai level pendekatan partisipatif (dialogis), berusaha untuk memperkenalkan pengolahan buah mangrove dan aneka jajanan. Level tertinggi merupakan level pengungkapan realitas dengan adanya observation deck, memungkinkan untuk melihat mangrove dengan sudut pandang berbeda mengenai ekosistem mangrove.

\section{Gagasan dan Proses Gubahan Massa}

Gagasan dalam mendesain

Dalam mengembangkan desain rancangan program Ekowisata Mangrove Muara Gembong, Bekasi dimulai dengan beberapa gagasan dalam mendesain sebagai gambaran awal suasana yang ingin dicapai dalam ekowisata mangrove. 


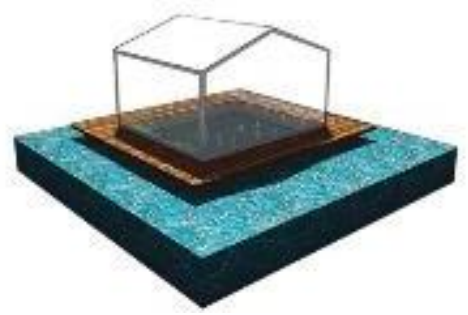

Gambar 7. Gagasan Dasar 1

Sumber: Ilustrasi Pribadi,2021

Adaptasi massa bangunan di aera mangrove yang tidak memiliki tanah padat tetapi juga berlumpur serta ada pula yang berbatasan langsung dengan bangunan. Pada area spa memiliki koneksi dan suasana berada di kawasan mangrove yang memberikan ketenangan dan pemandangan selama perawatan. Pembibitan mangrove menggunakan media gelas plastik bekas guna mempererat akar mangrove sehingga kemungkinan hidup mangrove menjadi lebih tinggi.

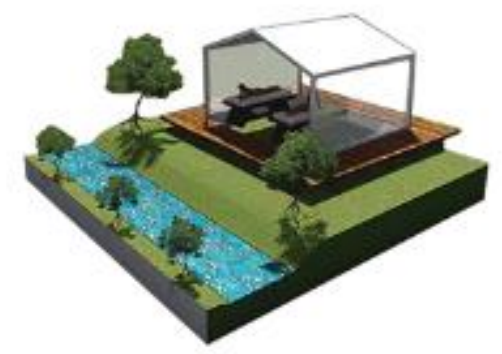

Gambar 8. Gagasan Dasar 2

Sumber: Ilustrasi Pribadi,2021

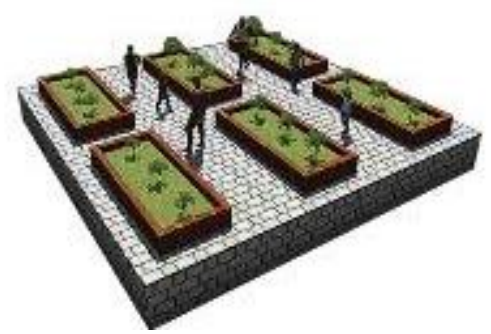

Gambar 9. Gagasan Dasar 3 Sumber: Ilustrasi Pribadi, 2021

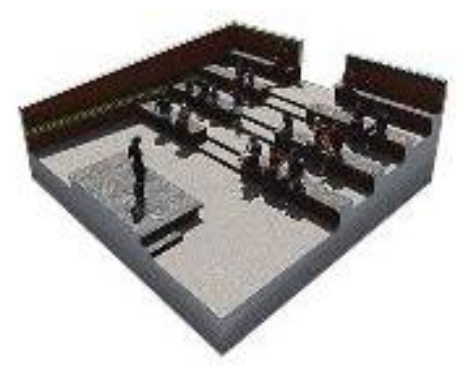

Gambar 10. Gagasan Dasar 4 Sumber: llustrasi Pribadi,2021

Balai pembibitan mengedukasi, memperlihatkan dan memberi gambaran awal sebelum pengunjung ikut serta menanam bibit mangrove. Area workshop dan ruang pengolahan yang terbuka untuk memperkenalkan dan memperlihatkan kepada pengunjung manfaat dan cara mengolah sebagai pemanfaatan buah dan daun kering dari mangrove, memberikan edukasi 
bahwa pembenihan dan penanaman mangrove dapat dimanfaatkan tidak hanya sebatas untuk lingkungan semata. Boardwalk pada area ekowisata yang memungkinkan sejumlah zona untuk pengunjung dapat berinteraksi dan merasakan mangrove secara lebih dekat.

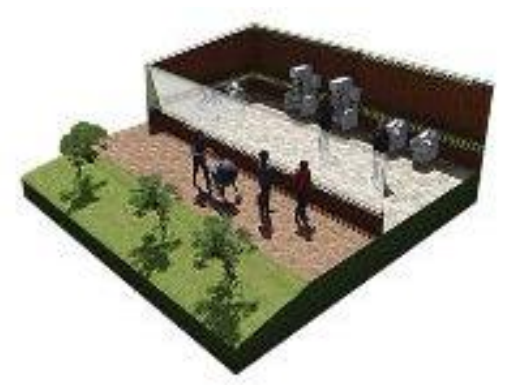

Gambar 11. Gagasan Dasar 5 Sumber: Ilustrasi Pribadi, 2021

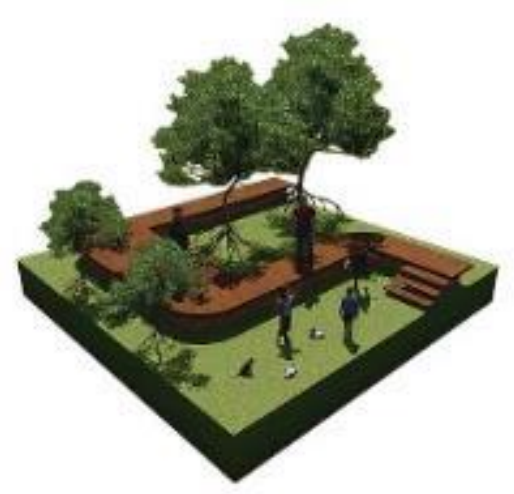

Gambar 12. Gagasan Dasar 6 Sumber: Ilustrasi Pribadi, 2021

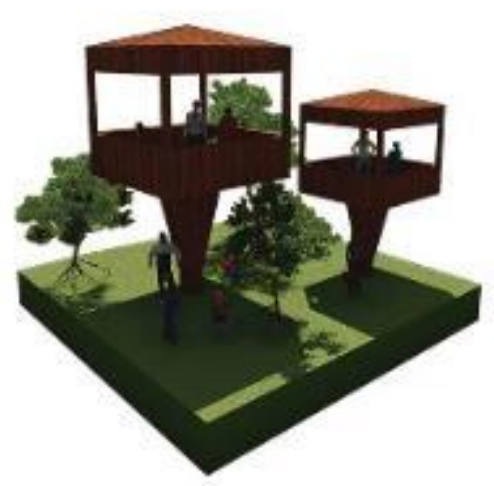

Gambar 13. Gagasan Dasar 7 Sumber: Ilustrasi Pribadi, 2021

Area layaknya sebuah rumah pohon untuk dapat melihat pemandangan mangrove dari level yang lebih tinggi dan dapat melihat ke lingkungan sekitarnya. Terdapat dermaga-dermaga kecil untuk naik dan turun penumpang tur mangrove menggunakan speed boat untuk mengelilingi taman mangrove didalam tapak untuk menjangkau area yang tidak terdapat boardwalk. Rekreasi menggunakan kayak dan pedal boat bagi pengunjung yang ingin menjelajahi taman mangrove secara lebih dekat sambil bermain. 


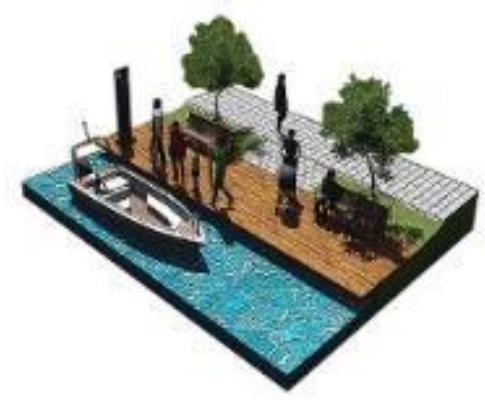

Gambar 14. Gagasan Dasar 8

Sumber: Ilustrasi Pribadi, 2021

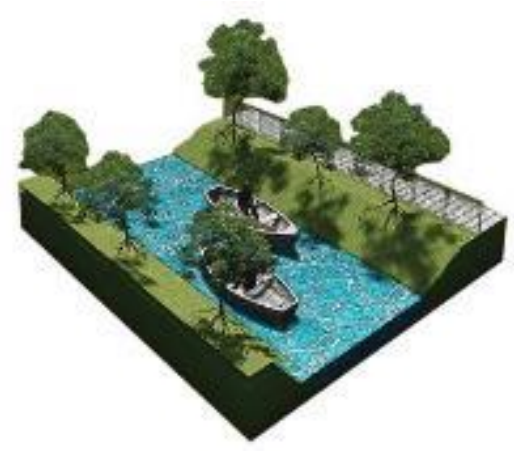

Gambar 15. Gagasan Dasar 9

Sumber: Ilustrasi Pribadi, 2021

\section{Proses Gubahan Massa}

Memperkecil platform tanah besar pada tapak rancangan untuk dikembalikan menjadi genangan air. Hal ini sehingga mangrove dapat tumbuh lebih dekat dengan massa bangunan tidak sebatas sebagai pemandangan dari jauh tetapi dapat merasakan berada di tengah-tengah ekosistem mangrove.

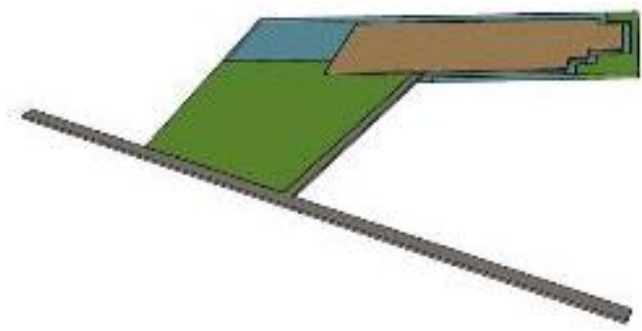

Gambar 16. Tapak Rancangan

Sumber: Ilustrasi Pribadi, 2021

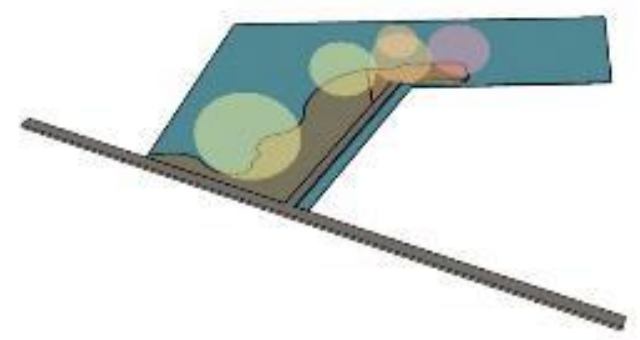

Gambar 17. Proses zonasi horizontal Sumber: Ilustrasi Pribadi, 2021 
Membagi zona horizontal berdasarkan intensitas sirkulasi pengunjung yang ada, taman mangrove (kuning) didekatkan dengan restoran yang memiliki intensitas sirkulasi pengunjung yang tinggi. Zona spa (merah muda) diletakkan menjauh mengingat intensitas pengunjungnya lebih rendah dan meningkatkan privasi sehingga pengunjung merasa nyaman ketika melakukan perawatan. Mengkombinasikan bentuk massa bangunan, massa bangunan restoran dibuat melingkar untuk memaksimalkan view kearah mangrove.

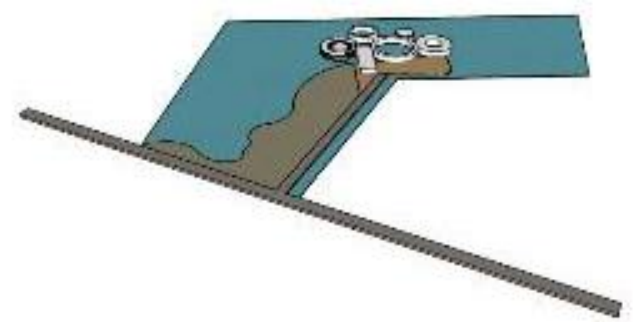

Gambar 18. Proses Gubahan Massa 1

Sumber: Ilustrasi Pribadi,2021

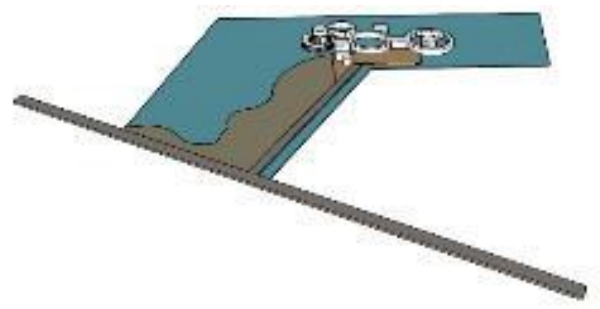

Gambar 19. Proses Gubahan Massa 2

Sumber: Ilustrasi Pribadi, 2021

Menarik massa spa menjauh dan melebarkan radius sehingga sirkulasi udara tidak terhalang dan view kearah mangrove menjadi lebih maksimal. Membuka massa spa menjadi massa-massa kecil, membatasi setiap unit dengan pohon mangrove untuk memberikan view dan privasi pada setiap unit massa spa. Boardwalk menghubungkan setiap massa mulai dari area taman mangrove hingga massa lainnya seperti restoran dan spa.

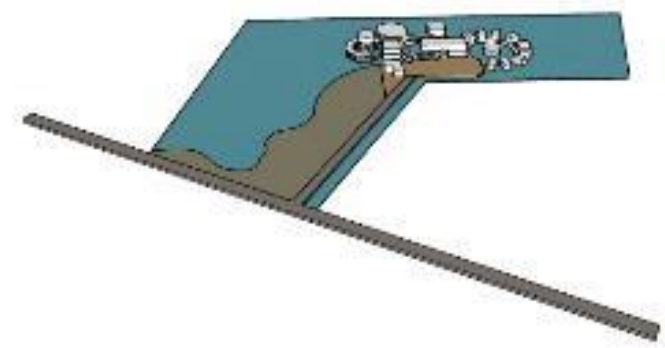

Gambar 20. Proses Gubahan Massa 3

Sumber: Ilustrasi Pribadi, 2021

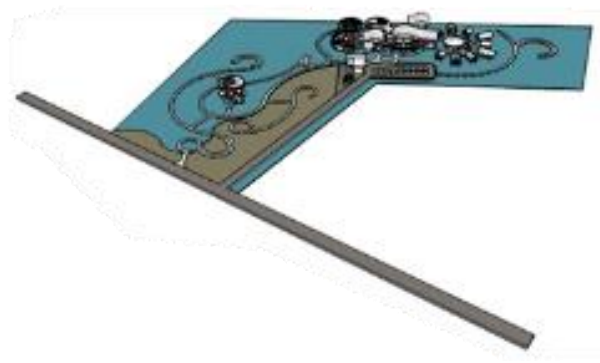

Gambar 21. Proses Gubahan Massa 4 Sumber: Ilustrasi Pribadi, 2021 


\section{Pemenuhan karakter Beyond Ecology}

Program Ekowisata Mangrove Muara Gembong, Bekasi memenuhi 5 kriteria dari 6 acuan kerja berarsitektur untuk tercapainya beyond ecology, kriteria yang terpenuhi yaitu Context (Dengan cara menaikkan massa bangunan sehingga tidak mengganggu lingkungan dan tidak terdampak bagi pasang surut air laut, memperkecil platform tanah besar pada tapak untuk dikembalikan menjadi air sehingga dapat ditumbuhi kembali oleh mangrove); Adaptation (Adaptasi massa bangunan dengan kondisi sekitar mangrove. Membuka massa untuk memperluas view serta pengadaan observation deck sehingga dapat melihat taman mangrove secara keseluruhan); Resilience (dengan cara menanam kembali mangrove, adanya program membenihkan dan menanam mangrove, memperkenalkan akan pentingnya mangrove dan manfaat mangrove didalam suatu ekosistem); Energy and Emission (memaksimalkan penggunaan pencahayaan dan pengudaraan alami didalam bangunan dengan membuka massa sehingga tidak menghalangi aliran udara); Sustainable Digital (mengembalikan sebagian besar platform tanah besar untuk dikembalikan menjadi genangan air sehingga dapat ditumbuhi kembali oleh mangrove).

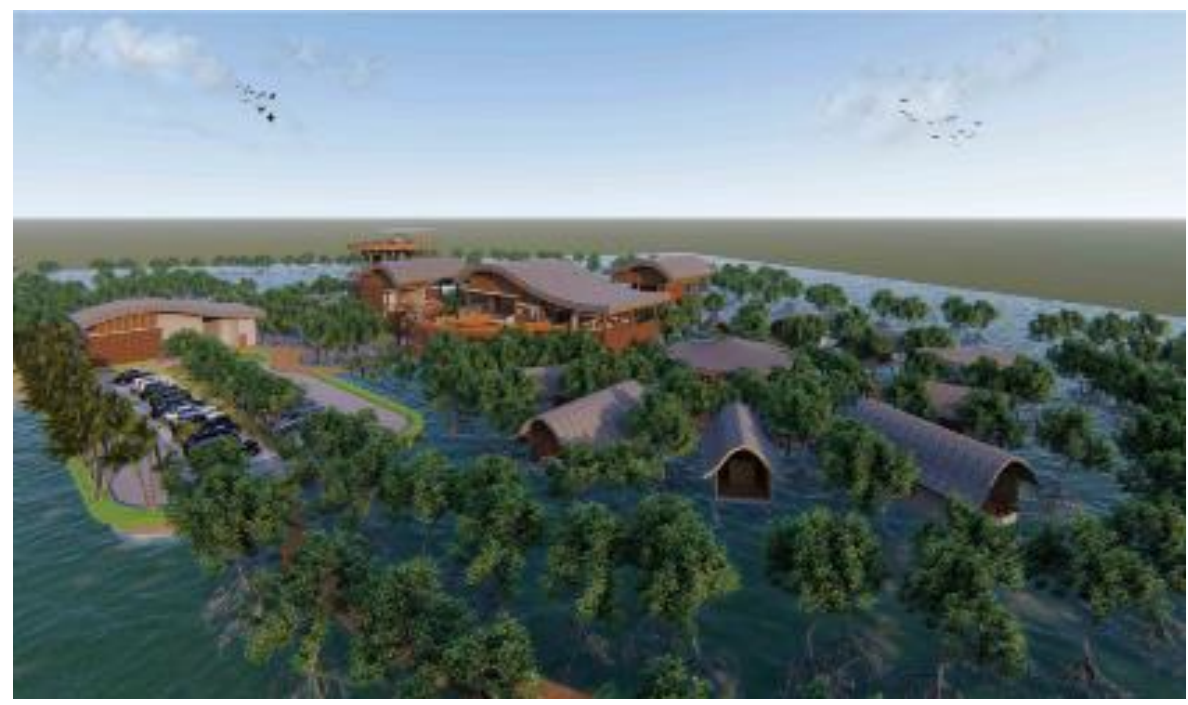

Gambar 22. Perspektif Ekowisata

Sumber: Dokumentasi Pribadi,2021

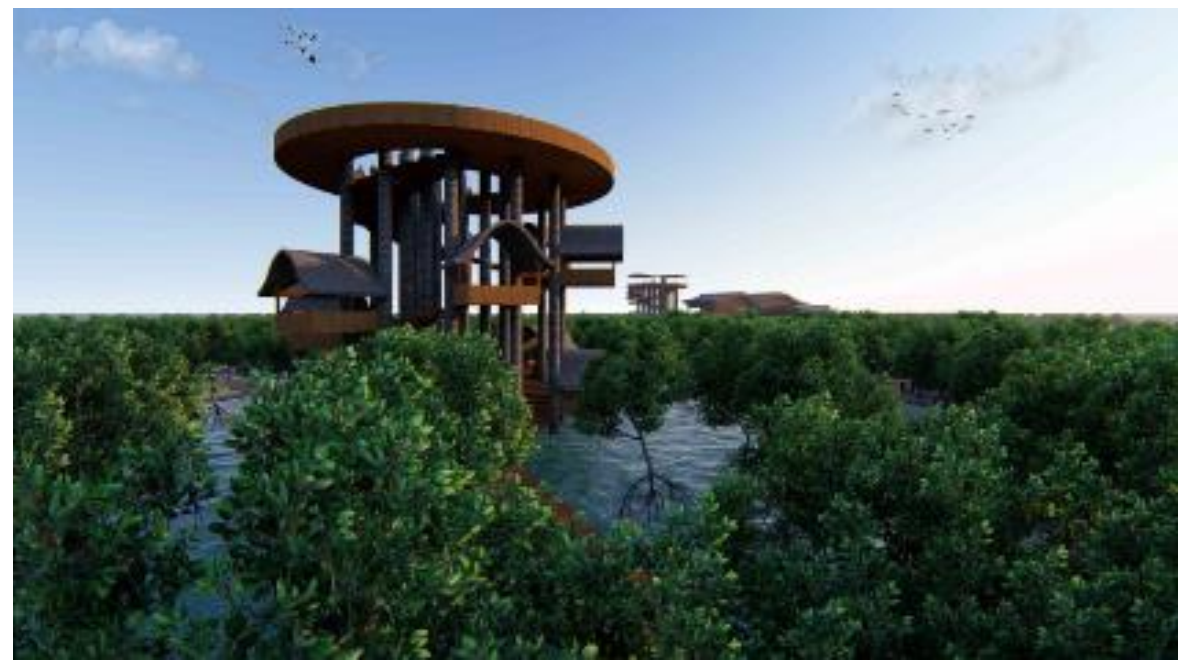

Gambar 23. Perspektif Observation Deck

Sumber: Dokumentasi Pribadi, 2021 


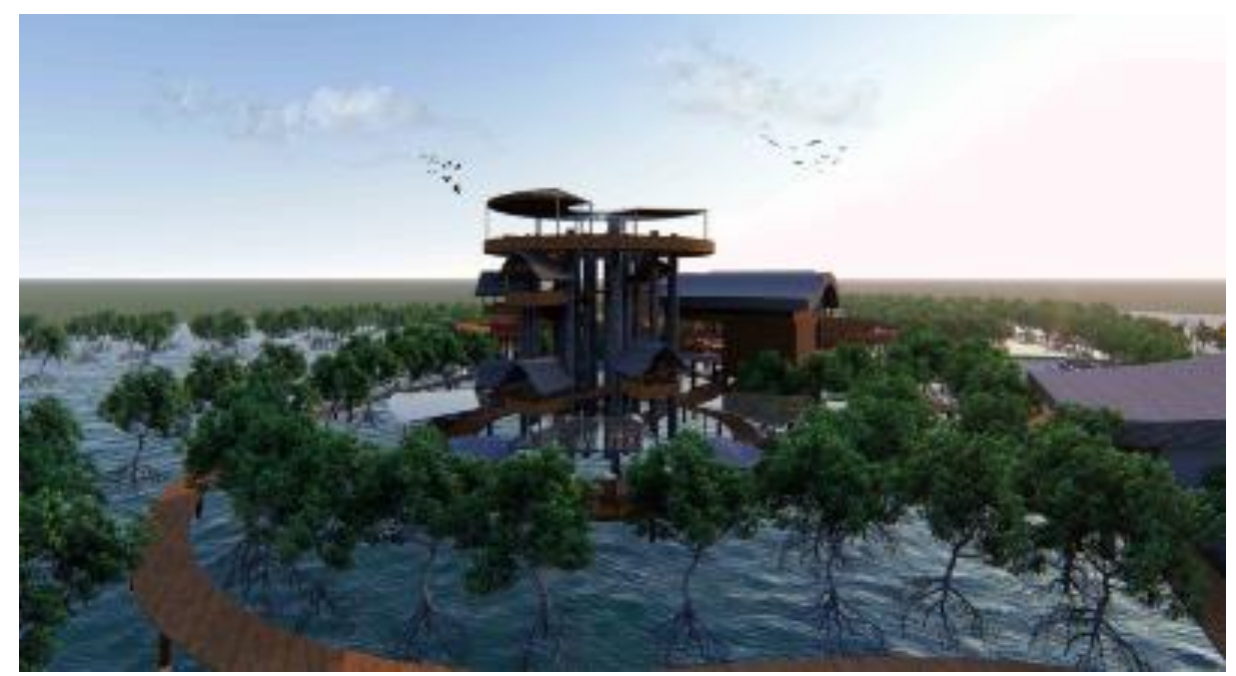

Gambar 24. Perspektif Ekowisata

Sumber: Dokumentasi Pribadi,2021

\section{KESIMPULAN DAN SARAN}

\section{Kesimpulan}

Proyek Ekowisata Mangrove berusaha untuk memberikan gambaran dan memberikan edukasi akan pentingnya menjaga ekosistem mangrove dengan adanya upaya membenihkan dan menanam mangrove yang tidak hanya untuk keberlangsungan lingkungan semata, tetapi juga menghadirkan nilai ekonomi bagi masyarakat dengan memperkenalkan pemanfaatan buah dan daun kering mangrove sehingga tidak perlu menebang pohon mangrove yang ada. Metode keseharian diterapkan untuk mengambarkan dan mencapai tujuan Ekowisata Mangrove dengan sederhana. Pemenuhan 5 karakter beyond ecology pada proyek rancangan yaitu context, adaptation, resilience, energy and emission, dan sustainable digital. Ekowisata Mangrove mampu menanggulangi dan menjadi wadah sebagai perantara dialogis kepada pengunjung dan masyarakat sekitar mengenai tujuan yang ingin dicapai yaitu memfasilitasi dalam upaya menanggulangi ketidakseimbangan akibat dampak eksploitasi mangrove terhadap kerusakan ekosistem mangrove dan degradasi mangrove, serta menjadi wadah untuk meningkatkan kesadaran dan kepedulian masyarakat akan pentingnya keberadaan mangrove yang tidak semata-mata hanya untuk kebaikan lingkungan semata.

\section{Saran}

Pengembangan rancangan lanjutan diharapkan nantinya aneka workshop dan pemanfaatan buah dan daun mangrove yang ada di ekowisata mangrove tidak disalah artikan sebagai bentuk eksploitasi baru melainkan upaya lainnya dalam usaha menjaga dan menyeimbangkan pemanfaatannya dengan cara yang bijaksana. Pengembangan yang disesuaikan kembali dengan tantangan, dan permasalahan dimasa depan sehingga beyond ecology yang dimaksud tidak hanya berhenti pada proyek ekowisata ini tetapi dapat disesuaikan terus menerus menjadi sebuah siklus baru.

\section{REFERENSI}

Donato, D.C., Kauffman, J. N., Murdiyarso, D., Kurnianto, S., Stidham, M., Kanninen, M. (2012). Mangrove adalah salah satu hutan terkaya karbon di kawasan tropis. Brief Cifor 12:1-4.

Kuswandono, K. (2018). The Distribution of Degraded Mangrove Ecosystem in Indonesia. Jakarta: Kementrian Koordinasi Maritim dan Kementrian Lingkungan Hidup dan Kehuranan. Maulani, A., Taufiq-SPJ, Pratikno, I. (2021). Perubahan Lahan Mangrove di Pesisir Muara Gembong, Bekasi, Jawa Barat (10(1),3-4). Universitas Diponegoro.

Sutanto, A. (2021). "Dromos Oikos" Notes on the fifth Ecology. Jakarta: kuliah tamu Tugas Akhir 
STUPA 8.31 Universitas Tarumanagara.

Sutanto, A. (2020). Peta Metode Desain. Jakarta: Universitas Tarumanagara.

Ana C, 2018, Mangrove dan Manfaatnya, diunduhkan 31 Januari 2021, <https://kkp.go.id/bdasukamandi/artikel/4239-mangrove-dan-manfaatnya>

CIFOR, 2015, CIFOR dan Indonesia Kemitraan untuk hutan dan manusia, diunduhkan 31 Januari 2021, <https://www.cifor.org/publications/pdf_files/Books/BCIFOR1402.pdf> 